\author{
전자식유량계를 활용한 홀스타인 젓소의 비유형질 분석 \\ 조광현* · 최준표** · 유병화*** • 이득환**** · 공홍식**** • 박경도**** • 이학교**** \\ 국립축산과학원*, JP솔루션**, 남양주시농업기술센터***, 국립한경대학교****
}

\title{
Analysis of Daily Milking Flow in Holstein Dairy Cow Using the LactoCorder
}

Kwang Hyun Cho*, Jun Pyo Choi**, Byung Wha You***, Deuk Hwan Lee****, Hong Sik Kong****, Kyung Do Park**** and Hak Kyo Lee****

National Institute of Animal Science, RDA*, JP Solution**, Namyangju Agricutural Extension Center***,

Hankyong National University****

\begin{abstract}
A total of 486 milk records were collected from 16 diary farms in Imsil-gun, Jeollabuk-do. Results obtained were as follows: The average 3MG (amount of milk within the first three minute) was $7.44 \mathrm{~kg}$ and $55 \%$ of total milk yield was produced within 3 min. The average of SPL (\% of foam in milk) was $33.93 \%$ and the average of MNG (strip yield) was $0.14 \mathrm{~kg}$, which was less than $1 \%$ of total milk yield. The averages of HMF (highest milk flow), HMG (maximum milk flow rate in one minute) and DMHG (average milk flow in the main milking phase) were $3.03 \mathrm{~kg} / \mathrm{min}, 2.94 \mathrm{~kg} / \mathrm{min}$ and $2.05 \mathrm{~kg} / \mathrm{min}$, respectively and the average milking speed in Imsil-gun was slower than other regions. The average of tS500(time to reach $0.5 \mathrm{~kg} / \mathrm{min}$ at beginning) was $0.23 \mathrm{~min}$ (about 14 seconds) and that of tMGG (duration of the total milking) was $7.75 \mathrm{~min}$. The average tMBG (duration of the dry milking phase) was $0.58 \mathrm{~min}$ (35 seconds) and that of tMNG (duration of the stripping phase) was $0.42 \mathrm{~min}$ (14 seconds). The averages of ELHMF (electrical conductivity at highest milk flow) and ELAP (beginning peak level of the electrical conductivity) were $6.81 \mathrm{mS} / \mathrm{cm}$ and $7.58 \mathrm{mS} / \mathrm{cm}$, respectively. The average of ELMAX (maximum electrical conductivity) was 7.48 $\mathrm{mS} / \mathrm{cm}$ and that of ELAD (beginning peak difference of the electrical conductivity) was $0.61 \mathrm{mS} / \mathrm{cm}$. While the total milk yields for DMHG, tMHG (duration of the main milking phase), tPL (duration of the plateau phase), tAB (duration of the descending phase) and tMGG were positively correlated (0.35 0.54), those for tMBG and SPL were negatively correlated $(-0.11$ and -0.27$)$. As the DMHG increased, tMHG, tPL, tAB, tMGG and SPL decreased. While the cows with higher electrical conductivity at the beginning of milking had less somatic cell counts, cows with higher electrical conductivity after the peak of milk yield had more somatic cell counts. The results of this experiment indicated that through milking based on milking and lactating standards and the regular checking of milking status, the qualities of milk and milk yields could be improved.
\end{abstract}

(Key words : Milk flow, tMGG, Electrical conductivity, Somatic cell)

\section{I. 서 론}

국내 호당 젓소의 사육두수는 2007년 기준 평균 59.2두 (농협중앙회, 2008)로 매년 꾸준히 증가하고 있고 아울러 착유관리에 소요되는 시간도 함께 증가됨에 따라 작업효 율은 중요한 경제적 요소가 되고 있다. 젖소 관리에 필요 한 시간은 두당 연간 50 80시간 정도이며, 이 중 대부분 이 착유시간에 소요되기 때문에(Schmidt 등, 1988) 노동력, 전기료 및 장시간 사용에 따른 장비의 노후 촉진과 매년 젖소 사육규모 증가에 따른 점 등을 고려하면 그 중요성
은 더욱 증가할 것이다. 따라서 착유실의 작업효율에 영 향을 미치는 비유지속시간, 비유속도 등과 같은 비유형질 이 낙농가의 관심을 끌게 되었다. 특히 비유지속시간은 착유실의 작업시간과 작업의 흐름 등에 영향을 미치고 유 질에도 영향을 미친다고 보고되었으며(Zwald 등, 2005), 외국에서는 종모우 평가에 비유속도 등이 활용되고 있는 반면 국내에서는 이에 대한 연구가 미비한 실정이다(안 등, 2005). 그러나 Boettcher 등(1988)은 비유속도 등이 지 나치게 빠르면 유두의 괄약근 약화로 세균 감염이 용이하 여 유방염에 잘 걸릴 수 있다고 보고하였으나 지나치게

Corresponding author : H. K. Lee, GRRC, Hankyong National University 67 Seokjeong-dong, Anseong-si, Gyeonggi-do, 456-749, Korea. Tel: 031-670-5490, E-mail: breedlee@empal.com 
늦으면 작업의 효율성이 떨어지고 착유기의 장시간 가동 등의 원인이 되므로 비유속도는 적당한 수준이 바람직하 다고 하였다. 과거에는 관리형질을 측정하기 위해서는 이 를 측정할 수 있는 착유시설이나 착유기의 구비가 선행되 어야 하는 어려움이 있었으나 최근 개발된 전자식유량계 (LactoCorder)를 이용하면 착유시 배출되는 유량을 측정하 고, 착유기의 정상작동 유무는 물론, 착유관리자의 올바른 착유방법여부, 유방 건강상태 등 그 결과를 그래프를 통 해 자료화하고 있어 낙농가의 기술수준향상을 통한 농가 수익증대를 기대할 수 있다. 또한 개체별 비유특성, 착유 압 등의 조절이 가능하며, 착유습관 개선을 통한 임상형 유방염 발생을 최소화 할 수 있으며, 착유상태 분석 및 표준화된 착유방법 지도와 현장 컨설팅을 통한 사후관리 실시 후 산유량을 증대할 수 있다. 따라서 본 연구의 목 적은 젓소의 유생산량 증가 및 유질개선을 위한 전자식유 량계(LactoCorder)의 활용방안을 소개하는데 있다.

\section{ㅍ. 재료 및 방법}

본 연구는 전라북도 임실군 관내 62농가를 사전 조사한 후, 이중 16 곳의 목장을 선정하여 총 486 두의 젓소에 대 한 개체별 비유성적자료를 검정요원 입회하에 2008년 10 월 한 달간 전자식유량계(LactoCorder)를 통하여 비유형질 과 착유습관 및 비유속도와 관련된 형질들을 수집하였다. 자료에 대한 통계처리는 SAS 9.1을 이용하였으며, 전기전 도도 관련 형질들과 체세포 수와의 회귀계수는 아래의 다 중회귀모형을 이용하여 추정하였다.

$$
Y_{i}=\beta_{0}+\sum_{j=1}^{k} \beta_{j} X_{i j}+e_{i}
$$

위에서, $Y_{i}=$ 체세포 수에 대한 관측치, $\beta_{0}=$ 절편, $\beta_{j}=j$ 번 째 전기전도도 형질에 대한 회귀계수 $(\mathrm{j}=1,2, \cdots, 7), \mathrm{X}_{\mathrm{ij}}=\mathrm{j}$
번째 전기전도도 형질에 대한 관측치, $\mathrm{e}_{\mathrm{i}}=$ 임의오차량이다.

\section{III. 결과 및 고찰}

\section{1. 임실군 낙농가의 일반 현황}

비유성적자료 수집에 앞서 임실군 관내 62곳의 낙농가 를 중심으로 경영관리 실태를 조사한 결과, 모두 우사내 사육을 실시하고 있었으며, 방목형태의 사육농가는 없었 다. 평균 착유두수는 30 여 두로서 일일 납유실적은 $800 \mathrm{~kg}$ 내외로 나타났으며, 목장주의 나이는 50 대가 전체의 $54.9 \%$ 로 가장 높게 나타났고 모든 목장이 자가경영을 하 는 것으로 조사되었다. 착유시설을 살펴보면 전체 농가 중 $45.2 \%$ 가 텐덤방식을 운영하고 있었고 그 다음으로 파 이프라인 착유시설이 전체의 $43.5 \%$ 를 차지하였으며, 바켓 과 헤링본 착유시설을 운영하는 농가는 각각 전체의 $8.1 \%$ 와 $3.2 \%$ 로 조사되었다. 총 62 곳의 목장 중 착유습관개선 컨설팅 낙농가 16 곳을 선정하여 검정요원 입회하에 전자 식유량계(LactoCorder)를 통하여 측정한 형질들은 크게 3 가지 형태로서 유생산량, 비유속도 및 전기전도와 관련된 형질들이었다.

\section{2. 유생산량 관련 형질}

유생산량과 관련된 형질들의 평균, 표준표차, 최소값 및 최대값은 Table 1에 제시하였다. 평균 일일 착유량은 두당 $26.6 \mathrm{~kg}$ 으로 전국평균 $29.8 \mathrm{~kg}$ 보다 낮게 나타난 반면, 평균 체세포 수는 전국 평균 21만/ml(농협중앙회, 2008)보다 낮 은 16 만/ml으로 유질면에 있어서는 전국 평균에 비하여 우 수하였다. 평균 비유개시 2분이내의 유량 $(2 \mathrm{MG})$ 은 $4.94 \mathrm{~kg}$ 으로 총 비유량 대비 $37 \%$ 로였으며, 이는 권장 수치 $50 \%$ 에 비하여 낮게 나타났다. 그리고 평균 비유개시 3분이내 유

Table 1. Mean, standard deviation(STD), minimum(Min), maximum(Max) and commentary for milk yield traits (number of cow $=486$ )

\begin{tabular}{lrrrrl}
\hline \multicolumn{1}{c}{ Traits } & Mean & STD & Min & Max & Commentary \\
\hline \hline MGG (kg) & 13.33 & 5.11 & 1.24 & 38.83 & Total amount milk(begin to end of measuring) \\
1MG (kg) & 2.13 & 1.16 & 0.39 & 8.94 & Amount of milk within the first minute \\
2MG (kg) & 4.94 & 2.38 & 0.93 & 18.69 & Amount of milk within the first two minute \\
3MG (kg) & 7.44 & 3.24 & 1.17 & 25.31 & Amount of milk within the first three minute \\
MNG (kg) & 0.14 & 0.54 & 0.00 & 7.72 & Strip yield \\
SPL (\%) & 33.93 & 17.81 & 4.00 & 79.00 & Percentage $(\%)$ of foam in milk measured \\
SCC $(10 \mathrm{cells} / \mathrm{ml})$ & 16.24 & 7.12 & 5.00 & 31.00 & Somatic cell counts \\
\hline
\end{tabular}


량 $(3 \mathrm{MG})$ 은 $7.44 \mathrm{~kg}$ 으로 총유량의 $55 \%$ 가 3 분이내에 비유되 는 것으로 조사되었으나 이 또한 권장 수치 $70 \%$ 에 비하여 낮게 나타나 초반 비유속도가 대체적으로 느린 것으로 조 사되었다. 평균 우유속 거품 함량(SPL)은 $33.93 \%$ 로 권장수 치 $20 \sim 30 \%$ 에 비하여 약간 높게 나타났으며, 평균 후착유 유량은(MNG)은 $0.14 \mathrm{~kg}$ 으로 총유량의 $1 \%$ 에 불과하였다.

\section{3. 착유속도 관련 형질}

착유속도 관련 형질들에 대한 평균 추정치는 Table 2에 제시하였다. 순간최고유속(HMF), 분당최고유속(HMG)과 주착유시평균유속 $(\mathrm{DMHG})$ 에 대한 평균치는 각각 3.03 $\mathrm{kg} / \mathrm{min}, 2.94 \mathrm{~kg} / \mathrm{min}$ 과 $2.05 \mathrm{~kg} / \mathrm{min}$ 으로 나타났으며, 세 형질 모두 각각의 권장수치 $4.0 \sim 5.0 \mathrm{~kg} / \mathrm{min}, \quad 3.5 \sim 4.5 \mathrm{~kg} / \mathrm{min}$ 과 $2.3 \sim 4.0 \mathrm{~kg} / \mathrm{min}$ 보다 낮게 나타남으로써 임실군 젖소군의 비유속도는 대체로 느린 것으로 조사되었다.

\section{4. 비유시간 관련 형질}

비유시간과 관련된 형질들에 대한 평균, 표준편차, 최소 치 및 최고치는 Table 3에 제시하였다. 비유개시부터 유속 $500 \mathrm{~g} / \mathrm{min}$ 도달시간(tS500)은 평균 0.23 분(약 14초)이었으며, 주비유시간(tMHG)과 총비유시간(tMGG)의 평균은 각각 6.65 분과 7.75 분으로 나타났다. 비유시간이 최장 22 분 이 상 걸리는 개체도 발견되었는데 이러한 원인은 착유 중 착유기를 떨어뜨리거나 착유기의 공기압이나 라이너의 부 적합 등 원인이 작용했을 것이라 생각된다. Plateau 착유시 소요되는 시간(tPL)은 평균 3.17 분이었으며, plateau 착유 이후 유속이 하강하는데 소요되는 시간 $(\mathrm{tAB})$ 은 평균 2.84 분 걸리는 것으로 조사되었다. 평균 과착유소요시간 (tMBG)은 0.58 분(35초)이며, 6 분 이상의 과착유 기록도 발 견되었다. 후착유소요시간(tMNG)은 평균 0.42 분(14초) 걸 리는 것으로 조사되었으며, 이러한 과착유 및 후착유의 소요시간은 착유자의 인위적 습관에서 야기되는 것이라

Table 2. Mean, standard deviation(STD), minimum(Min), maximum(Max) and commentary for milking flow traits (number of cow $=486$ )

\begin{tabular}{lccccl}
\hline \multicolumn{1}{c}{ Traits } & Mean & STD & Min & Max & \multicolumn{1}{c}{ Commentary } \\
\hline \hline HMF $(\mathrm{kg} / \mathrm{min})$ & 3.03 & 1.29 & 0.96 & 6.58 & Highest milk flow(within 22 second) \\
HMG $(\mathrm{kg} / \mathrm{min})$ & 2.94 & 1.24 & 0.94 & 6.14 & Maximum milk flow rate in one minute \\
DMHG $(\mathrm{kg} / \mathrm{min})$ & 2.05 & 0.74 & 0.64 & 5.05 & Average milk flow in the main milking phase \\
MFOS $(\mathrm{kg} / \mathrm{min})$ & 0.02 & 0.12 & 0.00 & 0.96 & Flow rate at begin of stripping $(\mathrm{OS}=1)$ \\
OS $(\%)$ & 0.05 & 0.22 & 0.00 & 1.00 & Stripping before reaching limit $(0.2 \mathrm{~kg} / \mathrm{min})$ \\
\hline
\end{tabular}

Table 3. Mean, standard deviation(STD), minimum(Min), maximum(Max) and commentary for milking time traits (number of cow $=486$ )

\begin{tabular}{llllrl}
\hline \multicolumn{1}{c}{ Traits } & Mean & STD & Min & Max & \multicolumn{1}{c}{ Commentary } \\
\hline \hline tS500 (min) & 0.23 & 0.10 & 0.00 & 1.12 & Time to reach 0.5kg/min at beginning \\
tAN (min) & 0.64 & 0.43 & 0.00 & 2.80 & Duration of the ascending phase \\
tAnD (min) & 0.25 & 0.27 & 0.00 & 1.21 & Time difference for recognizing plateau in ascending \\
tPL (min) & 3.17 & 1.97 & 0.00 & 15.07 & Duration of the plateau phase \\
tAB (min) & 2.84 & 1.69 & 0.14 & 17.08 & Duration of the descending phase \\
tAbD (min) & 0.39 & 0.96 & 0.00 & 16.15 & Time difference for recognizing plateau in descending \\
t400 (min) & 0.13 & 0.18 & 0.00 & 1.54 & Time to get from 0.4kg/min to 0.2kg/min \\
tMHG (min) & 6.65 & 2.62 & 1.12 & 22.17 & Duration of the main milking phase \\
tMBG (min) & 0.58 & 0.64 & 0.00 & 6.77 & Duration of the dry milking phase \\
tMBG2 (min) & 0.06 & 0.19 & 0.00 & 1.82 & Duration of the dry milking after stripping \\
tMNG (min) & 0.24 & 0.74 & 0.00 & 7.75 & Duration of the stripping phase \\
tHMF (min) & 2.76 & 1.57 & 0.19 & 11.53 & Time of the highest milk flow \\
tMGG (min) & 7.75 & 2.70 & 1.35 & 22.87 & Duration of the total milking \\
\hline
\end{tabular}


생각된다. 비유상승기 plateau 인식 소요시간(tAnD)과 비유 하강기 plateau 인식 소요시간(tAbD)은 평균 0.25 분(15초)와 0.36 분(21초)가 소요되었는데, 이는 개체의 스트레스 요인 과 비유시 변화하는 호르몬의 전이기전과 관계가 있는 것 으로 생각되며, 비유단계의 전이시간이 길어지는 현상은 주로 착유시에 가해지는 스트레스 요인에 의해 크게 영 향을 받는 것으로 생각된다.

\section{5. 전기전도도 관련 형질}

비유시간별 전기전도와 관련된 형질들의 평균, 표준편 차, 최소치 및 최대치를 추정하여 Table 4에 제시하였다. 최고유속시 전기전도도(ELHMF)와 비유개시시 최고전기전 도도(ELAP)의 평균은 각각 $6.81 \mathrm{mS} / \mathrm{cm}$ 와 $7.58 \mathrm{mS} / \mathrm{cm}$ 로 조 사되었고 최고유속이후 최고전기전도도(ELMAX)는 평균 $7.48 \mathrm{mS} / \mathrm{cm}$ 로 나타났다. 비유초기와 최고유속의 전기전도 도 차이(ELAD)는 평균 $0.61 \mathrm{mS} / \mathrm{cm}$ 로 나타났으며, 이러한
차이가 클수록 유방염에 걸렸을 확률이 높은 것으로 알려 졌다.

\section{6. 표현형 상관관계}

비유시간과 비유속도 및 비유량은 밀접한 관계가 있다 (Dzidic 등, 2004; 안 등, 2005). 총비유량 (MGG)은 주착유 시 평균유속 $(\mathrm{DMHG})$, 주착유시간 $(\mathrm{tMHG})$, Plateau 비유 소 요시간 $(\mathrm{tPL})$ 과 비유하강기 소요시간 $(\mathrm{tAB})$ 과 총착유시간 (tMGG)에 대하여 0.35 0.54 범위의 정 $(+)$ 의 상관관계를 나 타낸 반면, 과착유시간(tMBG)과 우유속 거품 함량 $(\mathrm{SPL})$ 과는 각각 -0.11 과 -0.27 의 부 $(-)$ 의 상관을 나타내었다 (Table 5). 즉 과착유시간과 유우속 거품 함량이 증가할수록 비유량은 감소하는 것으로 나타났다. 주비유시 평균유속 $(\mathrm{tMHG})$ 이 증가하면 총비유시간 $(\mathrm{tMHG})$, Plateau 비유 소요 시간 $(\mathrm{tPL})$, 비유하강기 소요시간 $(\mathrm{tAB})$, 총비유시간 $(\mathrm{tMGG})$ 과 우유속 거품 함량 (SPL)은 감소하며, 우유속 거품 함량이

Table 4. Mean, Standard deviation(STD), minimum(Min), maximum(Max) and commentary for electrical conductivity traits (number of cow $=486$ )

\begin{tabular}{lcrrrl}
\hline \multicolumn{1}{c}{ Parameter } & Mean & STD & Min & \multicolumn{1}{c}{ Max } & \multicolumn{1}{c}{ Commentary } \\
\hline \hline ELAP $(\mathrm{mS} / \mathrm{cm})$ & 7.58 & 1.16 & 0.00 & 10.22 & Beginning peak level of the electrical conductivity \\
ELAD $(\mathrm{mS} / \mathrm{cm})$ & 0.61 & 0.78 & 0.00 & 6.20 & Beginning peak difference of the electrical conductivity \\
ELHMF $(\mathrm{mS} / \mathrm{cm})$ & 6.81 & 0.69 & 4.85 & 11.72 & Electrical conductivity at highest milk flow \\
ELMAX $(\mathrm{mS} / \mathrm{cm})$ & 7.48 & 0.88 & 3.31 & 10.20 & Maximum electrical conductivity \\
ELST $(\mathrm{mS} / \mathrm{cm})$ & 1.01 & 1.23 & 0.00 & 5.68 & Step in the electrical conductivity \\
ELND $(\mathrm{mS} / \mathrm{cm})$ & 1.57 & 1.36 & 0.11 & 9.01 & Level difference of the electrical conductivity \\
ELMNG $(\mathrm{mS} / \mathrm{cm})$ & 5.37 & 1.95 & 0.00 & 10.21 & Maximum electrical conductivity after main milking \\
BIMO $(\mathrm{mS} / \mathrm{cm})$ & 0.31 & 0.46 & 0.00 & 1.00 & Bimodality \\
LE $(\%)$ & 0.04 & 0.19 & 0.00 & 1.00 & Abrupt air admission \\
\hline
\end{tabular}

Table 5. Correlation coefficients among milk yield, milking flow and milking time traits

\begin{tabular}{|c|c|c|c|c|c|c|c|}
\hline Traits & MGG & DMHG & tMHG & tPL & $\mathrm{tAB}$ & tMBG & TMGG \\
\hline DMHG & $0.54 * *$ & & & & & & \\
\hline tMHG & $0.53 * *$ & $-0.35^{* *}$ & & & & & \\
\hline tPL & $0.40 * *$ & $-0.28 * *$ & $0.76^{* *}$ & & & & \\
\hline $\mathrm{tAB}$ & $0.35 * *$ & $-0.25^{* *}$ & 0.70 ** & $0.10^{*}$ & & & \\
\hline tMBG & $-0.11 *$ & $-0.04^{\mathrm{ns}}$ & $-0.09 *$ & $-0.05^{\mathrm{ns}}$ & $-0.08^{\mathrm{ns}}$ & & \\
\hline tMGG & $0.49 * *$ & $-0.33 * *$ & $0.92 * *$ & $0.70 * *$ & $0.65^{* *}$ & $0.15 * *$ & \\
\hline SPL & $-0.27 * *$ & $-0.11 *$ & $-0.14 * *$ & $-0.12 * *$ & $-0.05^{\mathrm{ns}}$ & $0.01^{\mathrm{ns}}$ & $-0.13 * *$ \\
\hline
\end{tabular}

MGG : Total amount milk, DMHG : Average milk flow in the main milking phase, tMHG : Duration of the main milking phase, tPL : Duration of the plateau phase, tAB : Duration of the descending phase, tMBG : Duration of the dry milking phase, TMGG : Duration of the total milking, SPL : Percentage $(\%)$ of foam in milk measured ${ }^{*} \mathrm{P}<0.05,{ }^{*} \mathrm{P}<0.01,{ }^{\mathrm{NS}}$ none significant 
증가할수록 비유량 및 착유속도, 착유시간은 감소하는 것 으로 나타났다. 그리고 비유속도 및 비유시간 관련 형질 들은 대부분 정규분포를 이루고 있었다(Fig. 1).

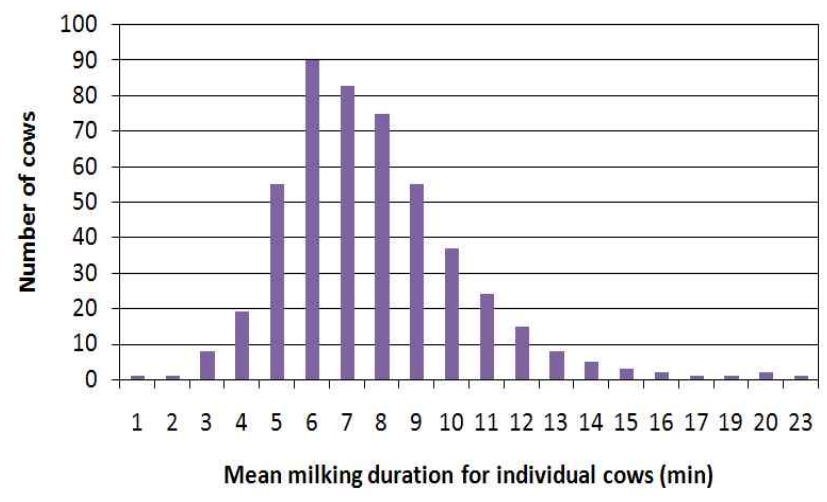

Fig. 1. Distribution of milk duration for individual cows.

7. 체세포 수와 전기전도도 관련형질과의 회귀식

전기전도도는 우유내 세포수와 밀접한 관계가 있다고 할 수 있는데 각 비유구간별 전기전도도와 체세포 수와의 관계를 살펴보면 비유개시시 전기전도도가 높은 개체의 우유는 체세포 수가 적은 반면 최고 비유기이후 최고전도 도가 높은 개체의 우유는 체세포 수가 높은 것으로 분석 되었으며, Table 6에 제시된 전기전도도 관련형질과 체세 포 수와의 다중회귀식은 $\mathrm{p}<0.01$ 에서 유의적 수준을 나타 내었다.

Table 6. Regression coefficients (b) of electrical conductivity traits for milk yield (MGG)

\begin{tabular}{lcc}
\hline Traits & $\mathrm{b}$ & $\operatorname{Pr}>|\mathrm{t}|$ \\
\hline \hline ELHMF & $-0.146^{\mathrm{NS}}$ & 0.443 \\
ELAP & $-0.513^{* *}$ & 0.000 \\
ELAD & $0.974^{* *}$ & 0.000 \\
ELMAX & $1.315^{* *}$ & 0.000 \\
ELST & $1.051^{* *}$ & 0.000 \\
ELND & $-0.301^{* *}$ & 0.044 \\
ELMNG & $0.024^{\mathrm{NS}}$ & 0.288 \\
\hline
\end{tabular}

$* \mathrm{p}<0.05, * * \mathrm{p}<0.01,{ }^{\mathrm{NS}}$ None significant.

\section{8. 비유곡선}

착유습관은 유생산량과 체세포 수와 밀접한 관계가 있 으며, 비유생리 또한 젖소의 건강상태와 밀접한 관계가 있다. 젖소의 비유곡선을 측정하여 착유습관, 착유시설 및
착유지도를 위한 대표적 비유 특성 사례들을 Fig. 2부터 Fig. 12까지 제시하였다. Fig. 2는 전반적으로 이상적인 비 유곡선을 나타내는 바람직한 형태이다. Fig. 3은 전착유를 하지 않은 경우 나타나는 비유곡선이며, 착유전 마사지가 부족한 경우에는 Fig. 4와 같은 특성이 나타난다. Fig. 5는 착유중 착유 유니트가 떨어진 경우를 보여주고 있으며, 이러한 현상은 공기압이 낮거나 개체가 불안정한 상태에 서 발로 착유 유니트를 떨어뜨린 경우라 하겠다. Fig. 6은 평균 비유속도가 매우 낮은 개체의 비유곡선을 나타낸 것

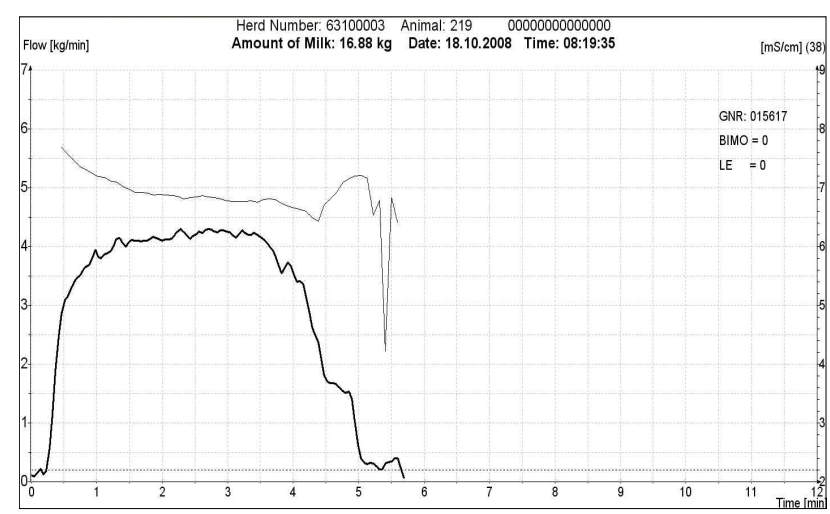

Fig. 2. In case of desirable milking type generally.

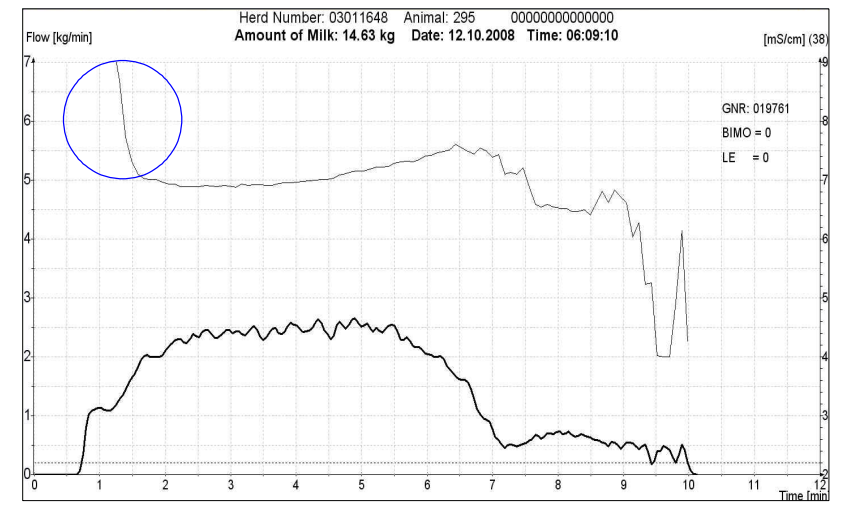

Fig. 3. In case of none pre-stimulation.

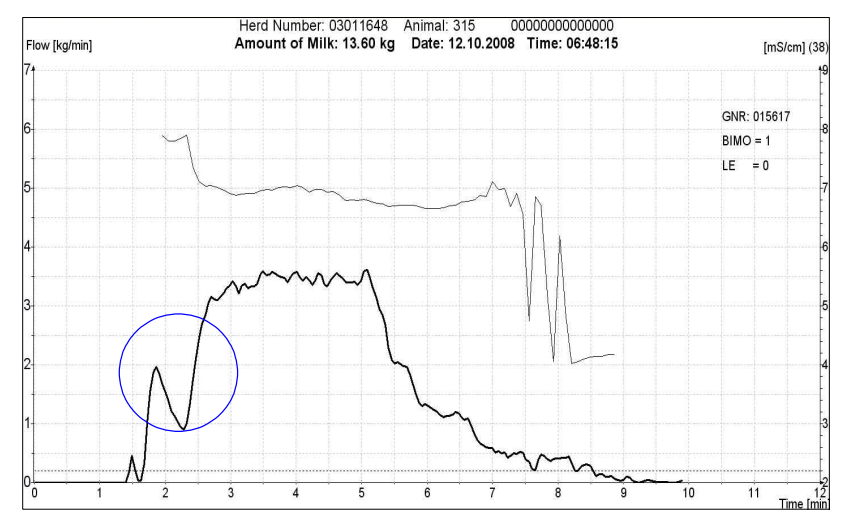

Fig. 4. In case of insufficient massage. 


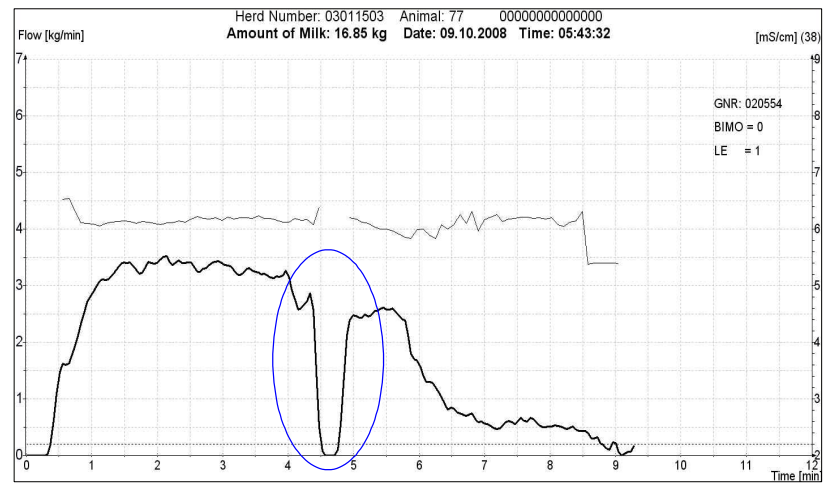

Fig. 5. In case of air leakage with gear falling off.

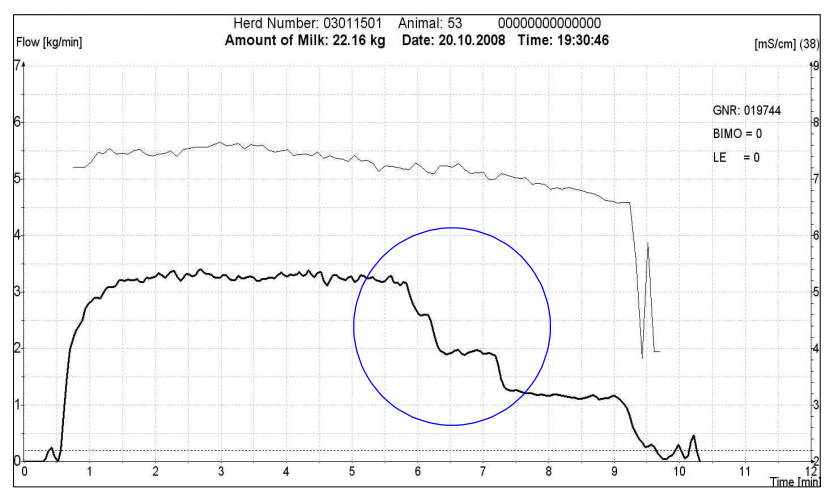

Fig. 7. In case of twisted unit.

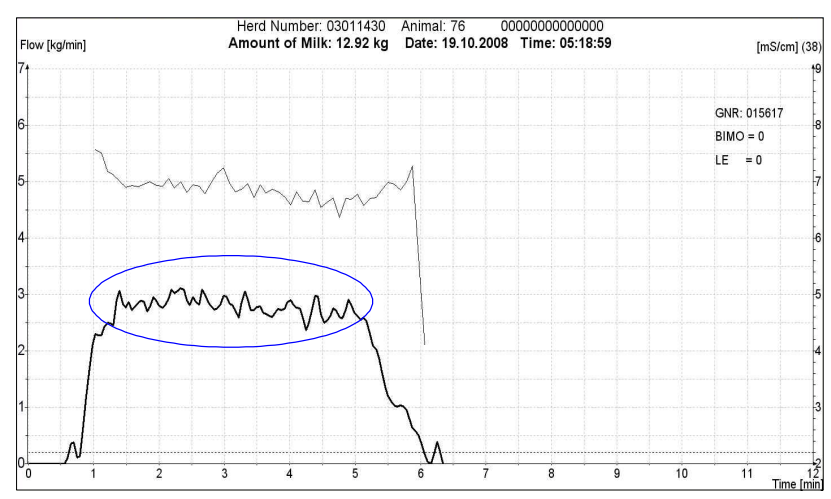

Fig. 9. In case of oscillating milk flow in stress.

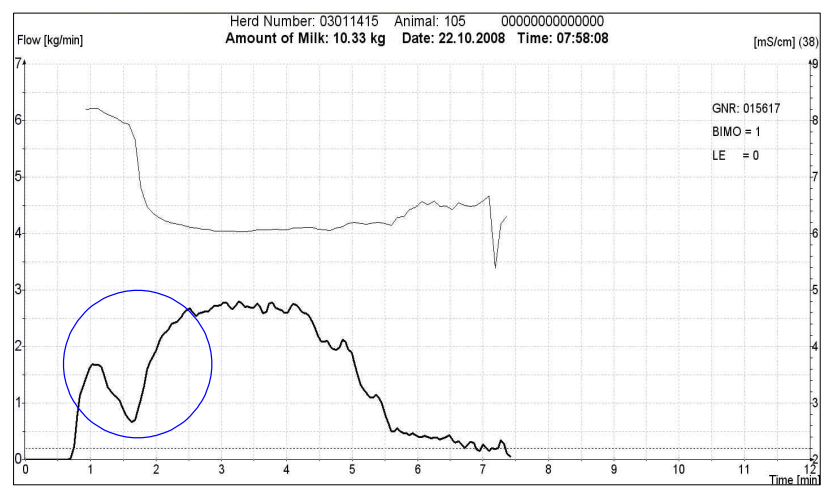

Fig. 11. In case of late unit attachment after massage.

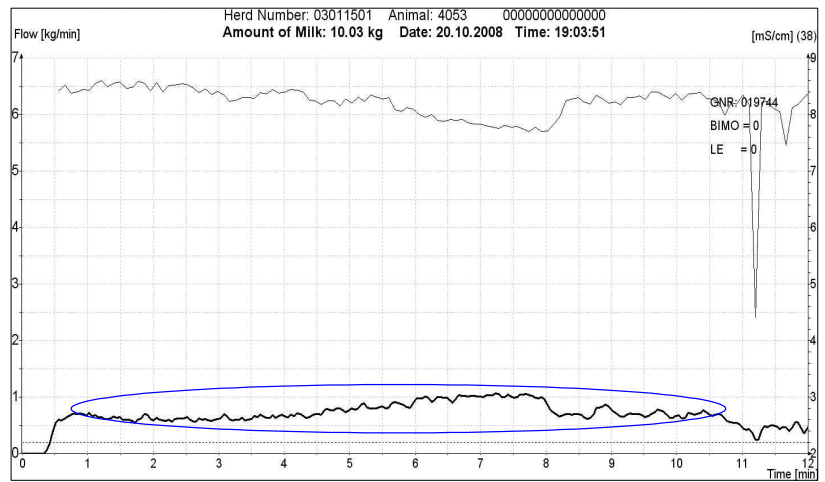

Fig. 6. In case of the lowest milk flow.

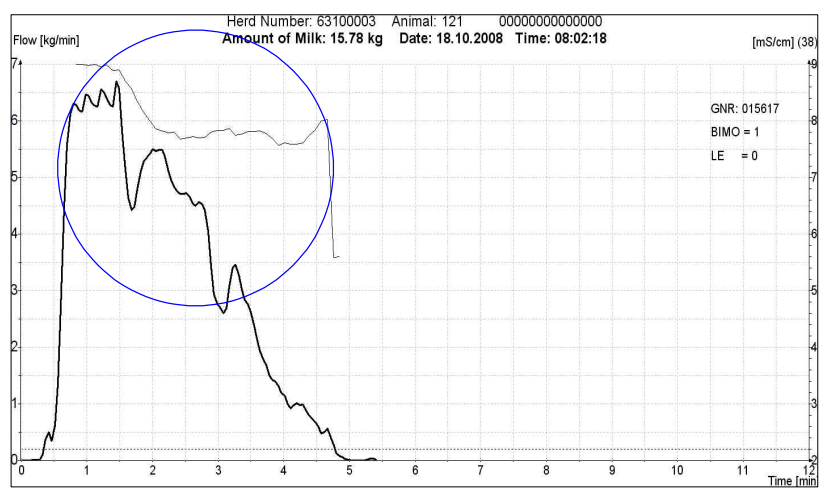

Fig. 8. In case of unfavorable peak flow level.

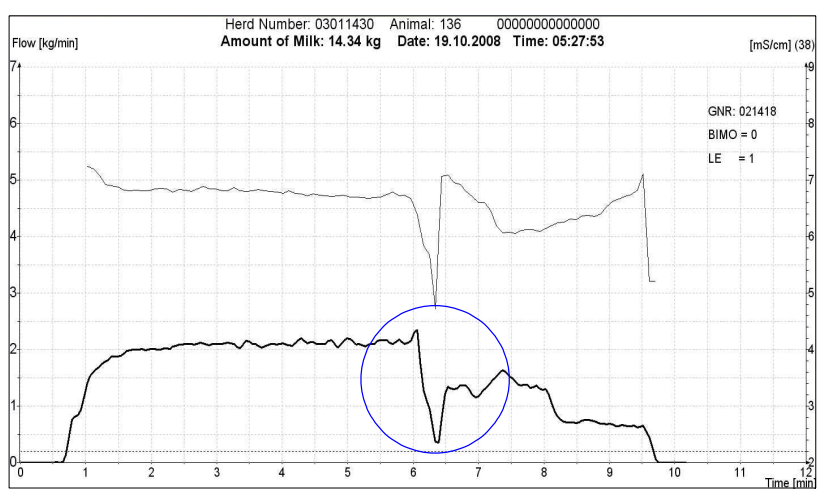

Fig. 10. In case of air leakage(liners slip).

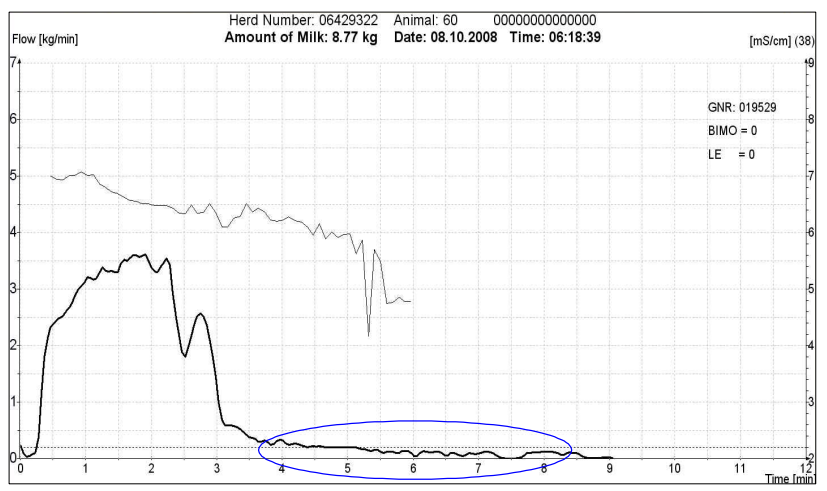

Fig. 12. In case of overmilking. 
이며, Fig. 7은 착유 도중 유니트가 비틀어진 경우에 나타 나는 현상이다. Fig. 8은 젖소의 유두 괄약근이 약하여 비 유 초기 유속이 매우 높게 나타나는 경우를 보여주는 것 이며, Fig. 9는 착유도중 젖소가 스트레스를 받은 상태에 서 나타나는 현상이다. Fig. 10은 착유중 라이너가 미끌어 진 상태이며, Fig. 11은 마사지후 착유기 부착이 늦은 경 우의 비유곡선을 보여주고 있다. 마지막으로 Fig. 12는 지 나친 과착유를 하는 경우에 나타나는 특징을 보여준다. 그리고 임실군 관내 16 곳의 목장에서 공통적으로 나타난 문제점은 대부분의 비유 특성 그래프에서 $\operatorname{ELAP}(\mathrm{mS} / \mathrm{cm})$ 의 수치가 높게 시작되었기 때문에 착유전 마사지가 부족 한 것으로 나타났다.

\section{$\mathrm{IV}$. 결 론}

대부분의 낙농가들은 착유시설에 대하여 높은 관심을 가지고 있으나 착유습관에 대해서는 표준안이 없고 낙농 가마다 각자의 습관에 의하여 착유를 실시하고 있다. 그 러나 착유습관은 유생산량과 체세포수 및 젖소의 건강과 도 밀접한 관계가 있기 때문에 착유 및 비유에 대한 표준 안을 바탕으로 착유를 실시하면 유량과 유질의 향상을 기 대할 수 있다고 본다. 따라서 전자식유량계(LactoCorder)를 활용한 비유상태를 정기적으로 점검하고 착유습관에 대한 평가를 실시하면 착유관리가 개선되어 한층 양질의 우유 를 생산함으로써 농가소득을 증대시킬 수 있을 뿐만 아니 라 비유 특성 자체가 개체의 건강상태, 즉 영양, 사양, 질 병, 유전, 번식 등의 지표로 활용될 수 있을 것으로 생각 된다.

\section{V. 요 약}

본 연구는 임실군 관내 16 농가를 선정하여 총 486 두에 대한 비유기록을 수집하였으며, 얻어진 결과는 다음과 같 다. 평균 비유개시 3 분이내 유량 $(3 \mathrm{MG})$ 은 $7.44 \mathrm{~kg}$ 으로 총 유량의 $55 \%$ 가 3 분이내에 비유되는 것으로 나타났고 평균 우유속 거품함량 (SPL)은 $33.93 \%$ 였으며, 평균 후착유 유량 은 $(\mathrm{MNG})$ 은 $0.14 \mathrm{~kg}$ 으로 총 유량의 $1 \%$ 에 불과하였다. 순 간최고유속 $(\mathrm{HMF})$, 분당최고유속 $(\mathrm{HMG})$ 과 주착유시평균유 속 $(\mathrm{DMHG})$ 에 대한 평균치는 각각 $3.03 \mathrm{~kg} / \mathrm{min}, 2.94 \mathrm{~kg} / \mathrm{min}$ 과 $2.05 \mathrm{~kg} / \mathrm{min}$ 으로 임실군 젖소군의 비유속도는 대체적으 로 느린 것으로 조사되었다. 비유개시부터 유속 $500 \mathrm{~g} / \mathrm{min}$ 도달시간 $(\mathrm{tS} 500)$ 은 평균 0.23 분(약 14초) 이었으며, 총비유 시간(tMGG)의 평균은 7.75 분이었다. 평균 과착유소요시간
(tMBG)은 0.58 분 (35초) 이었으며, 후착유소요시간 $(\mathrm{tMNG})$ 은 평균 0.42 분 (14초) 걸리는 것으로 조사되었다. 최고유 속시 전기전도도(ELHMF)와 비유개시시 최고전기전도도 (ELAP)의 평균은 각각 $6.81 \mathrm{mS} / \mathrm{cm}$ 와 $7.58 \mathrm{mS} / \mathrm{cm}$ 로 조사되 었고 최고유속이후 최고전기전도도(ELMAX)는 평균 7.48 $\mathrm{mS} / \mathrm{cm}$ 로 나타났으며, 비유초기와 최고유속의 전기전도도 차이 $(\mathrm{ELAD})$ 는 평균 $0.61 \mathrm{mS} / \mathrm{cm}$ 로 나타났다. 총비유량은 주착유시 평균유속 $(\mathrm{DMHG})$, 주착유시간 (tMHG), Plateau 비유 소요시간 $(\mathrm{tPL})$, 비유하강기 소요시간 $(\mathrm{tAB})$ 과 총착유 시간 $(\mathrm{tMGG})$ 에 대하여 $0.35 \sim 0.54$ 범위의 정 $(+)$ 의 상관관계 를 나타낸 반면, 과착유시간 $(\mathrm{tMBG})$ 과 우유속 거품함량 $(\mathrm{SPL})$ 과는 각각 -0.11 과 -0.27 의 부 $(-)$ 의 상관을 나타 내었다. 주착유시 평균유속 $(\mathrm{DMHG})$ 이 증가하면 총비유시 간 (tMHG), Plateau 비유 소요시간 (tPL), 비유하강기 소요 시간 $(\mathrm{tAB})$, 총비유시간 $(\mathrm{tMGG})$ 과 우유속 거품함량 $(\mathrm{SPL})$ 은 감소하는 것으로 나타났다. 비유개시시 전기전도도가 높 은 개체의 우유는 체세포 수가 적은 반면 최고 비유기 이후 최고전도도가 높은 개체의 우유는 체세포 수가 높 은 것으로 나타났다. 따라서 비유상태를 정기적으로 점 검하고 착유 및 비유에 대한 표준안을 바탕으로 착유를 실시하면 유량과 유질의 향상을 기대할 수 있다고 판단 되었다.

\section{VI. 사 사}

본 연구는 경기도에서 지원하는 '경기도지역 협력센터 사업(GRRC)' 지원비에 의하여 수행되었음.

\section{VII. 인 용 문 헌}

1. Boettcher, P. J., Dekkers, J. C. M. and Kolstad, B. W. 1998. Development of an udder health index for sire selection based on somatic cell score, udder conformation and milking speed. J. Dairy Sci. 81:1157-1168.

2. Dzidic, A., Kaps, M. and Bruckmaier, R. M. 2004. Machine milking of Istrian dairy crossbreed ewes : udder morphology and milking characteristics. Small Ruminant Research. 55:183189.

3. SAS User's Guide : Statistics, Ver 9.1 Edition. 1999. SAS Inst., Inc., Cary, NC.

4. Schmidt, G. H., Van Vleck, L. D. and Hutjens, M. F. 1988. Principles of dairy science. 2nd ed. pp 78.

5. Zwald, N. R., Weigel, K. A., Chang, Y. M., Welper, R. D. and 
Clay, J. S. 2005. Genetic evaluation of dairy sires for milking duration using electronically recorded milking times of their daughters. J. Dairy Sci. 88:1192-1198

6. 농협중앙회. 2008. 2007년도 한국 유우군 능력검정 사업보고 서. $\mathrm{p} 23-24$

7. 안병석, 전병순, 백광수, 박성재, 이현준, 이왕식, 김상범, 박수
봉, 김현섭, 주종철, 아즈말칸. 2005. 착유우의 연속유량, 유량 변이, 유성분, 체세포수, 비유지속시간, 비유속도에 대한 산차, 착유시간, 유기 및 착유간격의 효과. 한국동물자원과학회지. 47(6):919-924

(접수일자 : 2009. 6. 2. / 수정일자 : 2009. 7. 21. / 채택일자 : 2009. 8. 7.) 